Acta Biologica Plantarum Agriensis 5(1): 36 (2017) ISSN 2061-6716 (Print), 2063-6725 (Online) http://abpa.ektf.hu/
DOI:10.21406/abpa.2017.5.1.36

$4^{\text {th }}$ CC 2017 Abstract

Lecture

\title{
BIODIVERSITY OF BRYOPHILOUS PEZIZALES (ASCOMYCETES) IN HUNGARY
}

\author{
Briofil csészegombák Magyarországon
}

\section{Csaba NÉMETH}

MTA Centre for Ecological Research, Institute of Ecology and Botany, GINOP Sustainable Ecosystems Group, 8237 Tihany, Klebelsberg Kuno u. 3.; e-mail: nemetcsaba@gmail.com

Because of their tiny apothecia and special habitat bryophilous species of Pezizales belong to the overlooked and underrecorded groups of ascomycetous fungi, and many of them are represented only with a few localities worldwide. Particularly due to the activity of the bryologist Peter Erzberger (collector) and the mycologist Dieter Benkert (determinations) in the 1990s and the first part of the 2000s Hungary is one of the few countries that have fungistical data of bryoparasitic Pezizales at all. During systematic surveys in the last two years about 500 new occurrences of forty obligate bryophilous fungi taxonomically classified in the genera Lamprospora, Neottiella and Octospora have been observed in Hungary. Twenty of the taxa found are reported for the first time in the country and two of them seem to be new to science. By means of special parasitising structures (appressoria and haustoria) they parasitise mostly the rhizoids, rarely rhizoid tubers, stems, and leaves of various moss and liverwort species. The following taxa of bryophilous Pezizales were collected in the last two years in Hungary (bryophyte hosts indicated in brackets): Lamprospora dictydiola (Aloina ambigua, Tortula muralis), L. ditrichi (Ditrichum flexicaule), L. hispanica (Aloina ambigua), $L$. miniata var. miniata (Aloina ambigua., Phascum cuspidatum, Pottia spp.), L. miniata var. parvispora (Barbula unguiculata), L. miniata var. ratisbonensis (Didymodon spp.), L. minuta (Bryum sp.), L. retispora (Syntrichia ruralis), L. seaveri (Bryum spp.), L. tortulae-ruralis (Syntrichia ruralis), L. tuberculatella (Weissia sp.), Neottiella albocincta (Atrichum undulatum), N. ricciae (Riccia sorocarpa), Octospora axillaris var. axillaris (Phascum cuspidatum, P. curvicolle), O. axillaris var. tetraspora (Phascum cuspidatum), O. coccinea var. coccinea (Bryum spp., Encalypta vulgaris, very rarely Ceratodon purpureus), o. erzbergeri (Pseudoleskeella nervosa), O. excipulata (Aphanorhegma patens, Funaria hygrometrica), O. gemmicola var. gemmicola (Bryum spp.), O. gemmicola var. tetraspora (Bryum sp.), O. grimmiae (Grimmia pulvinata), O. gyalectoides (Aloina rigida, Barbula spp., Pottia spp., Phascum cuspidatum, Pterygoneurum ovatum, Tortula muralis, very rarely Bryum spp.), O. hetieri (Ceratodon purpureus), O. itzerottii (Pterygoneurum ovatum), 0. leucoloma var. leucoloma (Bryum argenteum, very rarely Bryum dichotomum), 0. leucoloma var. tetraspora (Bryum argenteum), O. lilacina (Pleuridium sp.), O. muscimuralis var. musci-muralis (Grimmia pulvinata), O. musci-muralis var. neglecta (Schistidium crassipilum), O. neerlandica (Syntrichia virescens), O. orthotrichi (Orthotrichum diaphanum), O. phagospora (Pohlia lutescens), O. pseudoampezzana (Schistidium crassipilum), O. rustica (Ceratodon purpureus), O. similis (Bryum sp.), O. wrightii (Amblystegium serpens). 